УДК 159.9.019.4:001.8(045)

Юрченко Вікторія

доктор психологічних наук, професор, професор кафедри психології ПВНЗ «Міжнародний економікогуманітарний університет імені академіка Степана Дем'янчука» http://orcid.org/0000-0001-4059-489X

Грищук Майя

кандидат психологічних наук, доцент, доцент кафедри психології ПВНЗ «Міжнародний економікогуманітарний університет імені академіка Степана Дем'янчука», http://orcid.org/0000-0001-7470-6960 DOI https://doi.org/10.35619/prap_rv.vi14.177

\title{
ТЕОРЕТИЧНІ ЗАСАДИ ДОСЛІДЖЕНЬ ВПЛИВУ СІМ'Ї НА НЕВРОТИЗАЦІЮ ДІТЕЙ ТА ШЛЯХІВ ЇЇ РАННЬОЇ ПСИХОКОРЕКЦІї
}

\begin{abstract}
Анотація. Стаття присвячена актуальній проблемі ранньої діагностики та психокорекиї невротизаиї школярів, спричиненої взаєминами в їхніх сім'ях. Проаналізовані провідні концептуальні положення наукової полеміки відомих вітчизняних та зарубіжних психологів щодо впливу сімейного оточення як на особливість психічного розвитку дітей та підлітків, так і на формування у них передумов до розладів поведінки. Уточнюється сутність понять дисфункиійна сім'я, нозочентриський та нормоцентриський підходи, доневротичні стани та невротичний розвиток особистості дитини. Отримані у ході дослідження результати вказують на те, щзо основні фактори невротизації школярів пов'язані із сім'єю та школою, причому сім'я створює постійне позитивне або негативне сочіально-психологічне середовище існування дитини. Зарубіжні та вітчизняні науковиі вважають сімейну психотерапію найбільш дієвим та розповсюдженим засобом психотерапї дитячих неврозів. При иьому виявлено, щзо у відповідних зарубіжних дослідженнях традиційно більше уваги приділяється психотерапевтичним методам, а у вітчизняних - медико-педагогічним.

В статті обтрунтована складність, багатокомпонентність предмету дослідження, необхідність застосування системних засобів вивчення та корекиії механізмів емоційно-вольової регуляиії і в поведінці дитини, $і$ в стосунках між нею та членами ї̈ сім '̈ як єдиної системи.

Ключові слова: дисфункиійна сім'я, нозочентриський та нормоцентриський підходи, доневротичні стани, невротичний розвиток.
\end{abstract}

Постановка проблеми. Проблема запобігання та корекції невротичного розвитку особистості дітей та підлітків належить до провідних інтересів психологічної науки як у суто науковому, так і в практичному вимірі. При цьому під час фронтального обстеження виявлено, що серед дітей з невротичними розладами психіки, тільки $20 \%$ були на обліку у психоневролога (Лебєдев). Виникнення та подальший розвиток афективно-обумовлених (психосоматичних) порушень, а також продуктивно-дизонтогенетичних феноменів регресивного характеру (наприклад, патологічних звичних дій - невроз нав'язливих дій), сприяють становленню більшості невротичних (патологічних) станів, особливо в ранні вікові періоди. Це вимагає максимально ранньої діагностики та корекції цих розладів через те, що вони взаємодоповнюють та підсилюють один одне, погіршуючи подальший прогноз.

Практична реалізація ранньої психопрофілактики та психокорекції невротичних розладів поведінки у дітей шкільного віку взаємопов'язана з активним залученням дитячих практичних психологів до цієї роботи, системним використанням ними адаптованих психологічних технологій та методів психотерапії як самої дитини, так іiі сімейного оточення. Але проблема дослідження розвитку, психопрофілактики та психокорекції невротичних розладів поведінки дитини буде розглянута однобічно, якщо не охарактеризувати відомі психологічній науці погляди щодо 
основних факторів невротизації школярів, аналіз та систематизація яких створює теоретичні засади цієї проблеми, без яких неможливе глибоке її вивчення та вирішення.

Аналіз останніх досліджень 3 проблеми. Дослідження теоретичних аспектів проблеми невротизації дітей шкільного віку безпосередньо пов'язане з вивченням провідних в медицині (психіатрії, психотерапії) та психології підходів до розмежування норми, патології та розладів психічної діяльності людини. Аналіз наукових доробок із цієї проблеми визначив об'єктивну доцільність діалектичного поєднання теоретико-методологічних засад нозоцентричного (Карвасарський, Гарбузов, Братусь, Захаров, Снікєєва, Ісаєв, Седнєв, Кемпінські, Фройд) та нормоцентричного (Бехтєрев, Мясищев, Лічко, Лисков, Юрченко, Роджерс, Перлз та ін.) напрямів оцінки та аналізу динаміки невротичних змін у психіці дорослої людини та дитини. Загалом у психології невроз визначають як функціональний розлад особистості, який виникає як реакція на значущі психотравмувальні події (конфлікти), має соціальну, нейрофізіологічну та психічну природу, обумовлюється недосконалістю механізмів психологічного захисту та антиципації. Теоретичний аналіз проблеми на підставі вивчення наукової літератури виявив необхідність застосування системних засобів вивчення механізмів емоційно-вольової регуляції і в поведінці дитини, і в стосунках між нею та членами її сім’ї як єдиної системи (Юрченко, 2006).

Натепер суть цього складного феномену розкрито в таких наукових доробках: концептуальні положення про психофізіологічну природу неврозу дорослої людини та дитини (Бехтєрєв, Ганнушкін, Кречмер, Мясищев, Лічко, Захаров, Карвасарський, Лисков, Ісаєв, Снєкєєва та ін.); концепції про взаємозв'язок невротичних розладів із особливостями психічного розвитку дітей та підлітків (Виготський, Кон, Титаренко, Ковальов, Фель, Аксоріна, Модіна, Фройд, Еріксон та ін.); принципи та методи системного дослідження психічних станів людини (Юрченко); теоретичні аспекти досліджень впливу умов виховання, взаємин у сім’ї на невротизацію дітей (Захаров, Ейдеміллер, Юстіцкіс, Семиченко, Заслуженюк, Палаццолі, Вітакер, Мінухін, Сюарт та ін.); принципи та методи системної сімейної психотерапії (Матурана, Варєла, Капра, Людевиг, Палаццолі, Вітакер, Мінухін та ін.).

Мета статті. Охарактеризувати теоретичні моделі основних факторів та чинників невротизації дітей шкільного віку, які утворюють теоретико-методологічні засади відповідної проблеми, що дозволить ефективніше вирішувати завдання, висунете перед психологічною наукою суспільством - психологічний супровід становлення гармонійної особистості дитини.

Виклад основного матеріалу дослідження. В загальній дискусії щодо проблеми невротизації психологічні школи використовують нозоцентристський та нормоцентриський підходи (Минухін, \& Фішман, 1998). Нозоцентриський підхід, який використовують знавці аномальних та хворобливих змін психічної діяльності, оцінює поведінку діяльності дітей та підлітків з позиції пошуку відхилень від норми, систематизації симптомів. Нормоцентриський підхід властивий знавцям «нормальної психіки». Вони пропонують оцінку психічної діяльності дітей та підлітків 3 позиції іï відповідності нормі. При цьому відхилення від «середньостатистичної норми» оцінюються як варіанти норми, прояви індивідуальних особливостей характеру особистості - як унікальний результат взаємодії індивідуальності та специфічних особливостей ситуації.

Дослідники різних психологічних шкіл: Мюнстерберг, Айзенк \& Рохман, Улман \& Краснер, Захаров. Бехтєрєв, Мясіщев та ін. пояснювали аномальну поведінку та хворобливі переживання через психологічні причини. Як реальні спостереження, так і використання сучасних психологічних методів патопсихологічного дослідження виявляють присутність різноманітних параметрів, які характеризують психічну діяльність дітей та підлітків в різних умовах, i, що $\epsilon$ найважливішим - широкий діапазон коливання цих параметрів (психофізіологічних показників, властивостей характеру, особливостей особистості та ін.) у різних особистостей. Невротичні реакції бувають рідкими, одиничними, але при несприятливих обставинах, при впливі на людину факторів, які послабляють іï адаптивні можливості, реакції частішають, стають систематичними, ускладнюються та поглиблюються за змістом. Природно, що при цьому з'являються підстави визначати стан нервово-психічної сфери як дохворобливий, доневротичний.

Прогностична значущість тої або іншої невротичної реакції визначається не стільки іiі тривалістю та глибиною розладу, на думку Scheff, Keupp, Cac, Bop, Hoffmann, Sullivan, Павлова, 
Карвасарського, Лазурського та ін., скільки загальною динамікою нервово-психічного стану, який обумовлюється і преморбідними чинниками і соціальним контекстом. Реакція може лишитись епізодом, який розвинувся у здорової людини та при нормалізації стану не лишить після себе ніяких слідів. В інших випадках реакція такого ж характеру при тій самій тривалості може спостерігатись у людини, яка вже знаходиться у хворобливому, невротичному стані, при цьому вона вписується в клініку неврозу як його складова частина.

Загальне співвідношення вищезгаданих станів можна представити у вигляді ланцюга 3 наступних ланок: одинична невротична реакція - невротичні реакції, які частішають та ускладнюються - доневротичний стан - клінічно сформований невроз -пролонговані невротичні стани, які повторюються - невротичний розвиток особистості («набута психопатія») (Грищук, 2010). При цьому дана послідовність не обов'язково зберігається. Хворобливі порушення можуть розпочатись з будь-якої ланки даного ланцюга, але при сприятливому перебігу подій, при вирішенні психотравмуючої ситуації, при нормалізації соматичного стану часто відслідковується зворотній розвиток нервово-психічних порушень, нормалізація стану.

Сімейне оточення має суттєве значення для розвитку патерну адаптації дитини (Бандура, 1999), тому появу емоційних розладів та дезадаптивної зміни поведінки в дослідженнях багатьох психологічних шкіл пов'язують 3 появою певних несприятливих подій в дитинстві людини, зі стосунками в сім'ї. На даний аспект звертають увагу Ейдиміллер, Захаров, 1998, Полтавец, Пєрвий, Жабокрицкий, 1998; Снєкеєва, 1998; Левіс, Лічко, Ремшмідт, 2002; Хорні, 1997; Бандура , Уолтерс, 1997 та інші. Серед основних сімейних чинників, що сприяють невротизації дітей шкільного віку, дослідники називають неадекватні стилі виховання, низький духовний та матеріальний рівень сім'ї, асоціальний або антисоціальний спосіб життя батьків, дисфункційність сім’ї (як форма дефіцитарності способів реалізації функцій сімейної системи), неповний склад сім'ї, неадекватні покарання.

При цьому взаємини дитини і сім’ї варто розглядати через взаємну проекцію впливів, стверджує прихильник психоаналітичної школи Аккерман (Ейдемиллер, Александрова \& Юстицький, 2000). Сім’я без дитини не є повною, так само, як і дитина без сім'ї. Дитина бере від сім'ї все необхідне для іiї росту та розвитку. В свою чергу і сім'я отримує від дитини все, що їй необхідно для власного росту та розвитку. Спостерігається взаємний вплив небажаних якостей на фоні взаємозалежних та взаємодоповнюючих стосунків. Діє обмін по колу взаємовпливів, які розповсюджуються в обох напрямах. Поведінку дитини, її виховання розглядають не тільки як похідне від особистості жінки-матері, але і як суперечливий прояв характеру та якості сім’ї в цілому. На думку Вітакєра (2001) сім'я створює особистість або руйнує іiі, сім'я сприяє укріпленню або підриву психічного здоров'я індивіда. Процес сімейної взаємодії вибірково контролює прояви емоцій, підтримує одні канали розрядки емоцій та пригнічує інші, особливо ті, які формують шизофренічний дефект. Сім'я заохочує одні особистісні потяги, одночасно забороняючи інші, задовольняє або забороняє особистісні потреби. Сім'я структурує можливості досягнення безпеки, задоволення та самореалізації. Вона вказує межі ідентифікації, сприяє появі у індивіда образу власного «Я». Сім'я окреслює небезпеки, з якими індивіду в своєму житті прийдеться стикнутись. Крім того вона надає конфлікту особливу форму, а також може створити сприятливі та несприятливі умови для пошуку рішення.

Групове життя сім’ї може сприяти підсиленню або послабленню тривоги, здійснюючи потужний вплив на успішність функціонування тих або інших захисних механізмів. Нарешті, сім'я може підсилити або послабити здатність індивіда до тестування реальності. Досліджуючи негритянські сім'ї Мінухін, вводить поняття «заплутаний клубок» (Минухін, \& Фішман, 1998). Таким чином, симптоматична поведінка дитини знаходить своє пояснення через патологічну близькість 3 іншими членами сім'ї. Емоційне захворювання може сприяти інтеграції або дезінтеграції сімейних взаємин, причому хвороба одного члена сім'ї може доповнювати хворобу іншого або протидіяти їй. Якість сімейних взаємин впливає на перебіг психічних розладів, прискорюючи або уповільнюючи їх. Деякі форми психічних розладів можуть стати спільними для більшості членів сім'ї.

Результатом досліджень та психотерапії Міланської групи (Сельвини Палаццолі, Босколо, Чеккін, \& Прата, 2002) стало виокремлення поведінки дитини - «цапка відбувала» 3 «брудної гри» 
батьків. Ці дослідники стверджують, що в усіх випадках анорексії та шизофренії має місце один процес. Початок - конфлікт між батьками, який завів їхні стосунки у глухий кут. До гри заохочується дитина, спочатку як спостерігач, а потім як активний учасник. Взаємини в конфлікті переструктуровуються. Щоб приборкати дивну поведінку дитини, батьки об'єднуються. Сімейна система здобуває рівновагу 3 симптомом хворобливої поведінки дитини в центрі. Сімейні конфлікти, дефіцит любові, смерть одного з батьків, батьківська жорстокість або просто непослідовність в системі покарань - ось далеко неповний перелік обставин, які травмують дитячу психіку. Першими у вітчизняній науці описали вплив викривленого сімейного виховання Бехтєрєв \& Сікорський (Ейдеміллер, Александрова \& Юстицький, 2000). Мягєр надрукував статтю про сімейну психотерапію при неврозах. Формування хворобливих станів, стійких невротичних розладів особистості Ейдиміллер та Юстіцкіс (2000) пов’язують із важливою та специфічною роллю сім’ї в розвитку дитини.

Стадії розвитку дитини та іiі чутливість до емоційної дезадаптації являють собою рівні біосоціальної інтеграції із сімейним оточенням та диференціації від нього, як стверджують Бєльський та Нікольський. На кожній стадії розвитку та дозрівання дитини ії спонукання, захист, сприйняття себе та оточуючих, конфлікт та тривога нагадують взаємопов'язані елементи адаптації в цілому. У своєму розвитку дитина проходить через різні рівні емоційної єдності із своїми батьками та сепарації від них. Звичайно, діти не завжди приймають моделі поведінки та погляди батьків. Це залежить як від життєвої необхідності, впливу інших людей, так і від характеру взаємин з самими батьками. Якщо стосунки є дисфункційними, діти можуть взагалі відмовитись від батьківських норм. До цього ж може призвести така поведінка батьків, яка викликає ще більші життєві труднощі та невдачі.

Чим більше сім'я дисфункційна, тим тісніше стосунки дитини і членів сім’ї пов'язані 3 темою емоційної жертви зі сторони індивіда як плати за приналежність та перебування в сім'ї. Дитина приносить таку жертву, приймаючи в тій або в іншій формі, в залежності від особливостей своєї сім’ї, роль «цапка відбувала». Крайня ступінь вираженості такого відношення проявляється в тому, що дитина відчуває заборону взагалі на своє існування, проміжна - на бути іншою. Упереджене ставлення до дитини може охоплювати ті якості, які несуть загрозу для батьків. Попередження може приймати форму неприйняття всього нового, будь-якого прояву зростання або змін; це може бути протидія висловлюванню іншої думки або спонтанному прояву почуттів. Часто упереджене ставлення стосується конфлікту молодшого і старшого покоління або протидії чоловічої та жіночої статі тощо. Нанесена емоційна травма дитині може призвести до: 1) істотної загрози виживанню дитини, що на фізичному рівні означає покинутість, голод, фізичний та або емоційний; 2) патологічного симбіозу дитини та одного з батьків, який перешкоджає розвитку дитини; 3) схильності до легкого або тяжкого психічного захворювання (Єнєкеєва; Сельвіні Палаццолі, Босколо, Чеккин, \& Прата, 2002).

Дитина здатна реагувати на небезпеку, яка виходить із сімейного оточення, наступним чином:

1. Вона може перейти у наступ та спробувати задовільнити свою потребу (агресивні розлади поведінки та соціопатії).

2. Дитина може відійти від контакту 3 сім'єю, що призводить до рецисивного особистісного розвитку або провокує тенденцію надмірного піклування про себе та своє тіло.

3. Дитина може давати сильну тривожну реакцію, з інтерналізацією в наступний розвиток психопатії в тій або іншій структурованій формі: а) надмірна тривога 3 інтерналізацією специфічного конфлікту та його інкапсуляцією, що має місце у випадку розвитку психоневротичної реакції; б) надмірна тривога, порушення емоційного контролю, декомпенсація захистів, параліч або дезорганізація адаптивних функцій, що може викликати соціопатичні або психосоматичні тенденції; в) надмірна тривога, дезорганізація адаптивної поведінки, зупинка розвитку іІабо регресія та реінтеграція на примітивному психічному рівні, як у випадку психотичних форм реагування.

Вивчення літературних джерел щодо впливу сімейного оточення як на розвиток дитини, так і на погіршення іiі адаптивних можливостей показало, що в історії становлення та розвитку вітчизняної та зарубіжної психології сім'ї сформувались дві групи теорій: 1) сім'я як джерело психічної 
травматизації особистості, формування невротичних станів дитини (Ейдеміллер, Юстіцкіс, Бєльський, Нікольський, Захаров, Вітакер, Аккерман та ін.); 2) невротизація особистості, психоемоційний дисбаланс дорослої людини та дитини як складові динамічно-циклічних процесів багаторівневої дисфункціональної системи сім'ї (Семиченко, Заслуженюк, Мінухін, Палаццолі, Стюарт, Джойнс та ін.). Саме друга група теорій розглядає невротизацію як процес захисної саморегуляції дитини (системи „дитина-батьки)” та системи сім'ї в цілому.

Нами створена та апробована авторська методика суб'єктивної експрес-діагностики рівня невротизації системи „дитина-батьки”, яка дозволила відібрати дітей з початковими невротичними станами та виключити з експериментальної вибірки осіб з клінічними формами неврозів, робота 3 якими не входить до компетенції шкільних психологів. Виявлена в дослідженні значуща негативна кореляція між одержаними суб'єктивними (інтегральні суб'єктивні показники рівня невротизації систем «дитина-батьки») та об'єктивними (інтегральні об'єктивні показники рівня невротизації дитини) даними підтвердила загальні теоретичні твердження системної сімейної психотерапії, що невротичні прояви (невротична реакція/реакції, стан) обстежених дітей мають інтрапсихічну та інтерпсихічну природу. Тобто початкову невротизацію можна тлумачити як процес захисної саморегуляції дитини (системи «дитина-батьки») та системи сім'ї в цілому. Адаптована і успішно апробована нами авторська технологія системної сімейної психотерапії як засіб психокорекції початкової невротизації дітей і підлітків може бути рекомендованою практичним психологам системи освіти України (Грищук, 2010).

Висновки і перспективи подальших розвідок. Мета статті, пов'язана 3 теоретичним аналізом проблеми впливу контексту сім'ї на невротизацію дітей шкільного віку, досягнута. Результати досліджень різних психологічних шкіл свідчать, що невротичні розлади психічної діяльності дітей та підлітків відбуваються в залежності і від певних преморбідних чинників, і від певних несприятливих подій в дитинстві людини.

У статті систематизовано накопичений досвід досліджень в даній проблемі таких вітчизняних та зарубіжних науковців, як: Єйдиміллер, Захаров, Полтавец, Пєрвий, Жабокрицкий, Єнєкеєва, Левіс, Лічко, Ремшмідт, Хорні, Бандура, Уолтер, Вітакер, Мінухін, Фішман, Нейпир, Сельвіні Палаццолі, Босколо,.Чеккин, Прата, Стюарт, Джойнс та ін. Серед основних сімейних чинників, що сприяють невротизації дітей шкільного віку, дослідники називають неадекватні стилі виховання, низький духовний та матеріальний рівень сім’і, асоціальний або антисоціальний спосіб життя батьків, дисфункційність сім'ї, неповний склад сім'ї, неадекватні покарання тощо. Наше дослідження довело, що дієвим засобом надання психологічної допомоги дітям є практична реалізація ранньої психопрофілактики та психокорекції невротичних розладів поведінки школярів шляхом активного залученням дитячих практичних психологів до цієї роботи, озброївши їх адаптованими психологічними технологіями та методами системної сімейної психотерапії як самої дитини, так і ії сімейного оточення.

Перспективи подальших досліджень:

- продовжити дослідження психологічних умов використання практичними психологами системи освіти України психотерапевтичних методів та технік як психологічного засобу профілактики та корекції невротичних розладів поведінки дітей шкільного віку (реакції протесту, відмови, імітації, групування $з$ однолітками, емансипації та ін.), аномалій розвитку їхньої особистості (акцентуації та психопатії);

- розробити алгоритм діагностики та корекції акцентуйованості (психопатії) молодших школярів та підлітків у контексті їхніх сімейних взаємин, яка може використовуватись психологами системи освіти України.

\section{СПИСОК ПОСИЛАНЬ}

Бандура, А., \& Уолтер, Р. (1999). Подростковая агрессия. Изучение влияния воспитания $u$ семейных отношений. Москва: ЭКСМО-Пресс.

Витакер, К., \& Бамбери, В. (2001). Танцы с семьёй. Москва: Класс. 
Грищук, М. М. (2010). Психопрофілактика та психокорекиія початкової невротизації дітей шкільного віку. (Автореф. дис. канд. психол. наук). Інститут психології імені Г. С. Костюка НАПН України, Київ.

Захаров, А. И. (1998). Неврозы у детей и психотерапия. Санкт-Петербург: СОЮЗ.

Енекеева, Д. Д. (1998). Пограничные состояния у детей и подростков: Основы психиатрических знаний. Москва: Academia.

Минухин, С., \& Фишман, Ч. (1998). Техники семейной терапии. Москва: Класс.

Нейпир, О., \& Витакер, К., (2005). Семья в кризисе: Опьт терапии одной семьи, преобразивший всю её жизнь. Москва: Когито - Центр.

Перре, М., \& Бауман, У. (2003). Клиническая психология. Санкт-Петербург: Питер.

Полтавец, В. И., Первый, В. С., \& Жабокрицкий, С. В. (1998). Агрессивное поведение при расстройствах личности. Днепропетровск: Атр-Пресс.

Ремшмидт, Х. (2002). Психология взросления. Подросток и семья. Самара: Издательский дом БАХРАХ.

Сельвини Палаццоли, М., Босколо, Л., Чеккин, Дж., \& Прата, Дж. (2002). Парадокс u контрпарадокс: Новая модель терапии семьи, вовлеченной в шизофреническое взаимодействие. Москва: Когито Центр.

Стюарт, Й., \& Джойнс, В. (2002). Основи ТА: транзакційний аналіз. Київ: ФАДА, ЛТД.

Хорни, К. (1997). Психология женщины; Невротическая личность нашего времени. Собрание сочинений в 3 m. (Т. 1). Москва: Смысл.

Эйдемиллер, Э. Г., Александрова Н. В., \& Юстицкий В. В. (2000). Семейная психотерапия. СанктПетербург: Питер.

Юрченко, В. М. (2006). Психічні стани людини: Системний опис. Рівне.

\section{REFERENCES}

Bandura, A., \& Uolter, R. (1999). Podrostkovaia agressyia. Yzuchenye vlyianyia vospytanyia y semeinykh otnoshenyi [Teenage Aggression. Studying the Effects of Parenting and Family Relationships]. Moskva: ЭKSMO-Press. [in Russian].

Vytaker, K., \& Bambery, V. (2001). Tantsy s sem'yey [Dancing with Family]. Moskva: Klass. [in Russian].

Hryshchuk, M. M. (2010). Psykhoprofilaktyka ta psykhokorektsiia pochatkovoi nevrotyzatsii ditei shkilnoho viku [Psychoprophylaxis and Psychocorrection of Primary Neuroticism of School-age Children]. (Avtoref. dys. kand. psykhol. nauk). Instytut psykholohii imeny H. S. Kostiuka NAPN Ukrainy, Kyiv. [in Ukrainian].

Zakharov, A. Y. (1998). Nevrozy u detei y psykhoterapyia [Neurosis in Children and Psychotherapy]. Sankt-Peterburg: SOIuZ. [in Russian].

Enekeeva, D. D. (1998). Pohranychnye sostoianyia u detei y podrostkov: Osnovbl psykhyatrycheskykh znanyi [Borderline Conditions in Children and Adolescents: The Basics of Psychiatric Knowledge]. Moskva: Academia. [in Russian].

Mynukhyn, S., \& Fyshman, Ch. (1998). Tekhnyky semeinoi terapyi [Family Therapy Techniques]. Moskva: Klass. [in Russian].

Neipyr, O., \& Vytaker, K., (2005). Semia v kryzyse: Opyt terapiyi odnoi semy, preobrazyvshyi vsiu yeye zhyzn [A family in crisis: The experience of single-family therapy that has transformed her whole life]. Moskva: Kohyto-Tsentr. [in Russian].

Perre, M., \& Bauman, U. (2003). Klynycheskaia psykholohyia [Clinical psychology]. Sankt-Peterburg: Pyter. [in Russian].

Poltavets, V. Y., Pervyi, V. S., \& Zhabokrytskyi, S. V. (1998). Ahressyvnoe povedenye pry rasstroistvakh lychnosty [Aggressive personality disorder]. Dnepropetrovsk: Atr-Press. [in Russian].

Remshmydt, Kh. (2002). Psykholohyia vzroslenyia. Podrostok y semia [Psychology of growing up. Teenager and family]. Samara: Yzdatelskyi dom BAKhRAKh. [in Russian].

Selvyny Palatstsoly, M., Boskolo, L., Chekkyn, Dzh., \& Prata, Dzh. (2002). Paradoks y kontrparadoks: Novaia model terapyy semy, vovlechennoi $v$ shyzofrenycheskoe vzaymodeistvye [Paradox and 
counterparadox: A new model of therapy for a family involved in schizophrenic interaction]. Moskva: Kohyto-Tsentr. [in Russian].

Stiuart, Y., \& Dzhoins, V. (2002). Osnovy TA: tranzaktsiinyi analiz [Fundamentals of TA: Transactional Analysis]. Kyiv: FADA, LTD. [in Ukrainian].

Khorny, K. (1997). Psykholohyia zhenshchyny; nevrotycheskaia lychnost nasheho vremeny [Psychology of women; The neurotic personality of our time]. Sobranye sochynenyi $v 3$ t. (T. 1). Moskva: Smysl. [in Russian].

Eidemyller, Э. H., Aleksandrova, N. V., \& Yustytskyi, V. V. (2000). Semeinaia psykhoterapyia. SanktPeterburg: Pyter. [in Russian].

Yurchenko, V. M. (2006). Psykhichni stany liudyny: systemnyi opys [Family therapy: System Description]. Rivne. [in Ukrainian].

\title{
THEORETICAL FUNDAMENTALS OF RESEARCH ON THE IMPACT OF THE FAMILY ON THE NEUROTIZATION OF CHILDREN AND WAYS OF EARLY PSYCHOCORRECTION
}

\author{
Yurchenko Victoria \\ Doctor of Psychology, \\ Professor of the Department of Psychology of the Higher Education Institution “ \\ International Economic and Humanitarian University named after Academician Stepan \\ Demyanchuk" \\ http://orcid.org/0000-0001-4059-489X \\ Grishchuk Maya \\ Candidate of Psychological Sciences, \\ Associate Professor of the Department of Psychology of the Higher Education \\ Institution "International Economic and Humanitarian University named after \\ Academician Stepan Demyanchuk" \\ http://orcid.org/0000-0001-7470-6960 \\ DOI https://doi.org/10.35619/prap_rv.vi14.177
}

\begin{abstract}
The article is devoted to the issue of early diagnostic and psychocorrection of neurotization of school-age children caused by their family relationships. Leading conceptual positions of scientific discussion of well-known domestic and foreign psychologists on the influence of family environment on specifics of mental development of children and adolescents, as well as on formation of their preconditions for conduct disorder, have been analyzed. The essence of the concepts of dysfunctional family, nosocentric and normocentric approaches, pre-neurotic states and neurotic development of the child's personality has been clarified. The results of the study indicate that the main factors in the neurotization of school-age children are related to family and school, with the family creating a permanent positive or negative social and psychological environment of the child's existence. Foreign and domestic scientists considerfamily psychotherapy the most effective and widespread means of psychotherapy of pediatric neuroses. At the same time, it has been found that in relevant foreign studies traditionally more attention is paid to psychotherapeutic methods, and in domestic - to medical and pedagogical.

The article substantiates the complexity and multicomponentity of the subject of study, the need to use systematic means of studying and correcting the mechanisms of emotional and volitional regulation in the behavior of the child and in relations between them and their family members as a single system.

Key words: dysfunctional family, nosocentric and normocentric approaches, pre-neurotic states, neurotic development.
\end{abstract}

